which more than 47,000 can be linked to layers dating from ca 1445 to the eighteenth century. As has been noted in other parts of the Arctic, Møhl observes very convincing temporal variability in species taken, apparently related to patterns of climate change in this largely ice-free zone. An expanded version of this appendix providing more discussion of the interactions of animals, hunters, and climate would be welcome, and it is hoped that this fine piece of zooarchaeology can be expanded in its own format in the future.

Overall, this clearly represents one of the most valuable books dealing with Greenlandic archaeology to be published for some time. Anyone with a concern for Inuit archaeology should acquire a copy while it is still in print. (Thomas H. McGovern, North Atlantic Biocultural Organization, Bioarchaeological Laboratory, Department of Anthropology, Hunter College, City University of New York, 695 Park Avenue, New York, NY 10021, USA.)

THE SILENCE CALLING: AUSTRALIANS IN ANTARCTICA 1947-97. Tim Bowden. 1997. St Leonards, NSW, and London: Allen \& Unwin. xxvii + 593 p, illustrated, hard cover. ISBN 1-86448-311-3. £40.00.

Flicking over the pages of a thick volume described as a history, and glimpsing long lists of names, makes one's heart sink. Such an impression proved entirely misleading with Tim Bowden's The silence calling. Having started, I read it, with enjoyment, right through - quite contrary to the code of practice of reviewers. As evidence of this involvement, I can state that in no less than five places in the text the reader is informed that the Lambert Glacier is the biggest in the world.

The persistent efforts of that greatest of Antarctic scientists, Douglas Mawson, to persuade the Australian government to consolidate its claims to $42 \%$ of the continent eventually led to the setting up in 1947 of the Australian National Antarctic Research Expedition (ANARE) as a civil service division fated to be passed on to a succession of different government departments. This is the point at which this history, which takes its title from a poem by Mawson, begins. Thereafter, Mawson continued to play an active but lesser and occasionally unhelpful role - as when he suggested that expeditions should be funded from commercial undertakings such as whaling. The first 19 years of the organisation were directed by another indomitable man, Phillip Law. It is well recognised that Antarctic science is highly dependent on politics and the story of Law's efforts to beat the system runs through most of the early chapters. A senior civil servant wrote of Law that he 'leaves the distinct impression that he does not want to act as a servant of the Government; he wants only to explore the Antarctic.' The provision of shipping proved particularly difficult, and for many seasons a chartered vessel, Kista Dan, was used with an unsuitable tank landing craft for servicing Heard and Macquarie islands. The first permanent foothold on the continent, Mawson Station, was commissioned in 1954, and the first RAAF flight took place from there in 1956. The International Geophysical Year, 1957-58, saw the USSR setting up three stations on Australian Antarctic Territory and consequently solving Law's political problems for him for the time being. The account of the subsequent negotiations leading to the Antarctic Treaty is interesting - the USSR supporting the concept of Antarctica being a nuclear-free zone, whilst Australia, with others, opposed it. Law retired from ANARE in 1966, frustrated by the government's refusal to allow his division to be responsible for its own research. The Mawson Institute, based in the University of Adelaide and modelled on the Scott Polar Research Institute, might have provided a research centre independent of government, but Law was convinced of the importance of keeping logistics and much of the science under his division's control. In spite of the efforts of Fred Jacka, who had worked on upper-air physics with ANARE, the Institute never became anything more than a collection of Mawson memorabilia and a director.

Law's successors in ANARE had no less trouble with bureaucracy and chaotic politics. A move of headquarters from Melbourne to Hobart was proposed in 1974 but was not completed until 1981. There was a black period with discontent in the Division, criticism from without, and dissension on policy within the government. Management consultants were unleashed on the Antarctic Division, and there was uproar over tenders for a new ice-breaking ship, culminating in police investigation, which, however, found no evidence of improper procedures. There was more trouble over the painstakingly thought-out Convention on the Regulation of Antarctic Mineral Resource Activities (CRAMRA), adopted by the Antarctic Treaty Consultative Parties in 1988. When it was first discussed by the Australian Cabinet, there was some objection on conservationist grounds, but a majority agreed that Australia should sign it. However, when it was found that France had reservations and when conservationists mounted an emotive campaign against it, the Convention was doomed. Had it been called the Convention for the Protection of the Antarctic Environment, a reasonable suggestion that was regarded as flippancy when the title was being discussed, there might well have been no trouble. Once again, science was overridden by politics. CCAMLR, the Convention for the Conservation of Antarctic Marine Living Resources, which came into force in 1982 and established its headquarters in Hobart, has, happily, been more successful in maintaining its scientific integrity. Another contentious issue faced by ANARE at that time was that of women in Antarctica, the first of whom, a medical officer, wintered on the continent in 1981. The story of what these unfortunate but resolute females went through is distressing. It was perhaps aggravated because their advent coincided with a rebuilding programme so that the ratio of 'tradies' - builders, carpenters, and mechanics with their traditional 'blokey' culture - to the more civilised 'boffins' was high. Now, women are accepted without question in every kind of ANARE activity. In spite of all these 
shenanigans, Australian Antarctic Territory was surveyed, and the total of sound and innovative science done in the 50 years of ANARE's existence is impressive.

This book gives much information and insight into the personnel, organisation, and politics of ANARE, which will be of great interest to the general reader on Antarctic matters and of particular value to the historian concerned with the interaction of science and politics. It has been carefully researched and annotated; the lists that attracted my initial attention should not have been disparaged they are useful records and are properly confined to appendices. The book is beautifully produced and the main text is enlivened by reminiscences and anecdotes. I was particularly fascinated by Syd Kirkby's report on the conditions encountered at the bottom of sleeping bags used as emergency photographic darkrooms. My only criticism is that in accounts of the science, the boundaries between the necessary background information and the achievements of ANARE are blurred so that it is difficult to know to what country specific advances are to be attributed. Not that this matters very much; Antarctic science has become an international venture to which Australia has made a worthy contribution. (G.E. Fogg, Bodolben, Llandegfan, Anglesey LL59 5TA.)

NATIVE LIBRARIES: CROSS-CULTURAL CONDITIONS IN THE CIRCUMPOLAR COUNTRIES.

Gordon Hills. 1997. London and Lanham, MD: Scarecrow Press. xvi + 361 p, illustrated, hard cover. ISBN 0-81083138-4. \$US59.50.

In this book, author Gordon Hills raises issues of what an ideal library serving indigenous peoples should be. Drawing largely upon his personal experiences as a librarian working in several native American communities, Hills comments not just about libraries, but also about cultural identity, social conditions, multiculturalism, literacy and orthographies, and other topics. The book is a series of bibliographies coupled with essays, photographs, and appendices.

Although much of the book focuses upon Alaska, library-related topics of other circumpolar regions are covered: pre- and post-peristroika Russia, Canada, Greenland, and contemporary library services in northern Scandinavia. Hills' selectively annotatea jibliographies in multiple sections reveal the literature in English about libraries and circumpolar native peoples through 1995. These bibliographies are the substance of the book and will be of particular interest to researchers and librarians.

The chapter 7 title, 'A potpourri...,' best describes the book. The individual chapters are informative and provocative, and sometimes also redundant. Extraneous material clings to the chapters. An editor could have improved the book by fact-checking - such as 'village corporations were established by Alaska State law' (page ix) - paring the text, and unifying the sections.

Hills' chapter on oral and written traditions thoughtfully discusses the concept of a library in indigenous communities. Native peoples' histories and contemporary experiences are being documented through 'traditional knowledge' programs that are increasingly common in the Arctic regions. Several native American groups are developing 'cultural centers' that collect the standard library references about their own cultures (many of which are rare and out-of-print but now available in microform or CD-ROM formats); these cultural centers also record elders on audio- and videotape, and provide the museum functions of collecting, curating, and interpreting cultural items.

Hills documents several attempts to provide library services during native peoples' transitions from subsistence to cash economies and migrations from rural to urban locations. He chronicles efforts to provide such services to the Alaskan Yup'ik Eskimo people in the delta of the Yukon and Kuskokwim rivers.

National library policy is an interesting thread throughout the book. Most of the circumpolar nations have such public policies, but the inclusion of native peoples has been largely recent and inadequate. Hills' reviews of Canadian, Greenlandic, and Russian policies are very informative. US library services to native peoples have been largely local or regional, serious national policy emerging only since the late 1970s.

Having selectively surveyed the literature on native peoples and libraries in the circumpolar north, Hills' work is a major contribution. (Ron Inouye, Bibliography of Alaska and Polar Regions, Rasmuson Library, University of Alaska Fairbanks, Fairbanks, AK 99775-6808, USA.)

\section{WAKE OF THE INVERCAULD: SHIPWRECKED IN THE SUB-ANTARCTIC: A GREAT-GRAND- DAUGHTER'S PILGRIMAGE. Madelene Ferguson Allen. 1997. Montreal, Kingston, London, and Buffalo: McGill-Queen's University Press. 256 p, illustrated, hard cover. ISBN 0-7735-1688-3. \$Can 19.95.}

The sub-Antarctic islands have been the scene of many shipwrecks, in particular during the nineteenth and early twentieth centuries, when maritime technology had advanced sufficiently to make navigation in the "furious fifties' comparatively safe, but when it had not advanced to the point at which isolated islands (and icebergs) could be detected before it was too late. The motivating force behind the selection of routes that exposed ships to this risk was, of course, that of cost. If voyaging, for example, from the Cape of Good Hope to Australia, the great circle route offered considerable savings in distance covered and, hence, in time en route. However, there was always the concomitant risk of falling in with one of the many imperfectly charted island groups, and this could easily be fatal at night or in foul weather.

The Auckland Islands, in New Zealand's sub-Antarctic territories, were the scene of several such wrecks and one of them, that of Invercauld, which met her end in 1864, is the subject of this book. A seaman on board the vessel, Robert Holding, wrote an account of the voyage, of the 